\title{
The Guangzhou 2010 Asian Para Games: \\ The Preparation, Performance, Evaluation and Recommendations \\ of The Hong Kong, China Delegation \\ 廣州2010年亞殘運會：中國香港代表團的賽前準備、 \\ 比賽中的表現、賽後檢討及建議
}

\author{
Patrick NG \\ Hong Kong Paralympic Committee \& Sports Association \\ for the Physically Disabled
}

伍澤連

香港殘疾人奧委會暨傷殘人士體育協會

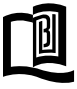

\begin{abstract}
The Guangzhou 2010 Asian Para Games was hosted between 12-19 December 2010 in Guangzhou. It was the first major para-international sporting event after the successful organization of the 2008 Beijing Paralympics. The writer, as the Chef de Mission, with the feeling of "Thank you \& Appreciation" and the perspective of both management and technicality, depicted comprehensively the preparation, performance, evaluation and recommendations of the Hong Kong, China Delegation. It is hoped that personnel of both the Hong Kong Paralympic Committee and sports fraternity would be able to share the joy and happiness of the delegation in Guangzhou, and parts of the content could well be as reference for report writing.
\end{abstract}

\section{摘 要}

「廣州2010年亞殘運會」於2010年12月12日至19日假廣州擧行，這是從2008年北京殘奧會後首個大型的殘疾人士體育盛會。 本文作者以中國香港代表團團長身份, 用「感謝及欣賞」的心情, 並以行政管理及技術層面角度描繪代表團賽前的準備、比賽中 的表現、賽後檢討及建議作一全面報告(伍澤連，2011)，並得執委會確認，願與香港殘奧會同寅及體育界友好一同分享在廣州舉辦 的亞殘運會, 盼望後學能借鑑有關內容, 作日後撰寫報告之用。

\section{(一) 引言}

$1.1 「$ 廣州2010年亞殘運會」(簡稱「亞殘運會」) 共41個亞 洲國家/地區殘奧會2522名運動員參加。自2006年最後 一屆遠南運動會後, 便升格為亞洲殘疾人運動會。香 港殘疾人奥委會暨傷殘人士體育協會(簡稱「香港殘奧 會」)自創會以來，今次選派最龐大的代表團(107名運動 員及62名工作人員)參加首屆在廣州擧行的亞殘運會, 於19大項(註1)中競逐14大項獎牌, 計有田徑、射箭、羽
毛球、硬地滾球、柔道、賽艇、射擊、游泳、乒乓球、 保齡球、擧重、輪椅籃球、輪椅劍擊及輪椅網球。

1.2 作者擔任國際殘疾人運動會團長多年, 帶領港隊出賽, 每次經歷不同。今次嘗盡酸甜苦樂, 即使面對困難障 礙, 均能克服及迎刃而解; 代表團不錯是龐大, 但絕不 會出亂子, 正因為上下一心, 在講求團隊精神的大前 提下------教練、運動員、醫療隊伍及秘書處同事相互合 
作, 無分你我, 各項事工均能妥善安排, 順利完成。 作為代表團團長, 以「銘感於心」的心情, 以行政管 理(秘書處為主導) 及技術層面 (主教練為主導) 的角 度, 在下列三個範籌撰寫報告, 向代表團成員及支持者 致以由衷的感謝, 並與香港殘奧會同寅及體育界友好分 享一切有關亞殘運會工作歷程, 並予以共勉 :

* 賽前的準備 ;

* 比賽中的表現 ;

* 賽後檢討及建議。

\section{（二）賽前的準備}

2.1 為了參加廣州亞殘運會, 香港殘奧會秘書處、教練們和 運動員已準備一年多, 每周訓練次數之頻密, 遠較過往 備戰遠南運動會為甚, 可想而知他們所付出的心力、汗 水和體力之多。由於 2010 年亦是各殘疾人士單項運動世 界錦標賽年, 部分項目運動員更勤加練習, 冀望搶分成 功, 達標取得倫敦殘奧入場券。因此安排場地和增加訓 練乃刻不容緩------海外訓練、本地集宿、每周甚或7次 訓練，以至增加體能訓練等不同元素。

2.2 自 2010 年開始, 香港殘奧會與亞組委緊密聯絡, 索 取最新資料, 可惜所獲資料甚少, 5 月從 A P C (亞 殘奧會)（註2）獲悉, 若要參加亞殘運會, 必須符合 $\mathrm{MQS}$ (最低參賽標準)，與過往遠南運動會不限報名 人數(當中必須包括 $30 \%$ 新秀運動員) 有 180 度的轉 變。經秘書處屢次向 $\mathrm{APC}$ 諮詢及反映------由於時間短 促, MQS對大部分國家/地區殘奥會未及準備、適應, 實不合理和有欠公允。結果於最後報名時APC從善如 流, 因應各地殘奧會實際精沉, 靈活處理, 部分項目報 名不需要MQS或不受世界排名影響, 但香港殘奧會教

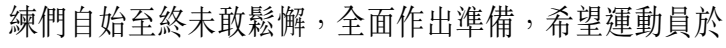
報名前達至MQS。

2.3 在 2010 年 5 月的團長會議後, 秘書處與亞組委緊密聯 繫, 其轄下的NPG（地區殘奧會）聯絡員給予極大的 協助, 各項事工雖然繁瑣, 都能一一解決。由於亞組委 大量資料在不同時間傳送至香港殘奧會, 秘書處同事經 分工後 (多聘兼職一名)，與教練們增强溝通，增加到 訪各項目訓練, 秘書處與教練和運動員因而建立良好關 係, 對各項目更添了解。

2.4 訓練後期, 醫療人員和運動心理學家的積極投入, 參與 運動員的訓練, 認識運動員, 了解他們的傷患, 探究他 們的表現是否受心理因素影響等, 乃直接加强運動員對 醫療隊伍及運動心理學家的信任。
2.52010 年 8 月的輪椅網球、輪椅籃球及硬地滾球 測試賽（註 3 ），是給予運動員賽前熟悉場地 和了解環境的好機會; 同時, 秘書處亦兩度前 赴廣州，嘗試及探討香港殘奧會 170 人的代表 團, 以陸路抑海路前赴廣州參賽及返港為佳。 3球隊參加測試賽後獲益良多, 秘書處亦確認海路為最 佳往返交通工具。

2.6 由於運動員報名和工作人員、義工及嘉賓註冊是分開進 行, 秘書處需要為他們全部註冊, 故人數達259名（其 中 60 名為嘉賓)，涉及輸入大量資料及核對工作。同 樣地有關代表團資料、賽程及網頁（於 12 月 5 日香港殘 奧會會員大會後啟動）等亦由專人負責，希望於比賽期 間, 外界能即時取得第一手消息。

2.7 香港殘奧會一改以往傳統, 今次代表團出賽沒有安排授 旗禮, 沒有編印特刊, 卻以記者招待會（2010年10月 23日）及派發專業印製的代表團單張（見附件）取而代 之, 簡單隆重, 甚獲好評。

\section{（三）比賽中的表現}

3.1 代表團先鋒部隊於 2010 年 12 月 6 日出發, 在選手村進行 註冊工作, 妥善安排代表團入住選手村及準備有關訓練 及比賽, 讓大隊於 12 月 8 日抵埗後, 省卻不少麻煩。

3.2 代表團教練會議基本上在晚上擧行, 相互交換及聽取意 見, 教練或其他工作人員若遇有困難或問題，管理層將 予以支援, 建議可行的解決方案或向亞組委反映, 要求 相應的協助; 會後並進行簡短的秘書處會議, 跟進有關 事項及安排翌日工作。另團長會議亦於每天早上擧行, 由亞組委主持, 透過會議, 發放大會消息及應注意事項 (如開幕式、閉幕式及升旗禮等)，聽取各代表團所遇 困難及提出意見, 繼而予以跟進。

3.3 每晚8時開始, 醫療隊伍亦進行診症, 替運動員治療傷 患, 賽事開始初期, 工作至深夜。與此同時, 公關及市 務部同事亦胼手胝足，忙於編輯當日所攝錄影片及照 片, 撰寫比賽摘要及運動員的表現, 上載香港殘奧會中 國香港代表團網頁（2010），供香港傳媒使用，然後才 進食晚腷。

3.4 由於秘書處同事已預先分工, 緊貼各項比賽, 與醫療隊伍 協作,支援各小隊之餘, 更為運動員打氣, 整理當日成績, 匯報公關及市務部, 以便第一時間攝錄及發放; 晚上再由 專責同事綜合整體成績及翌日賽程, 上載上網供各界人士 參考。由於大會祇供應一台電腦, 供上載功能, 與在賽前 預期有所出入, 故每晚工作需延至深夜才告完成。 
3.5 經過整年的備戰, 教練的縝密部署, 運動員的努力拼 搏及各方的全面支援，在比賽中，大部分運動員表現 不錯，經驗豐富的精英運動員固然得心應手，延續過 往成績，部分項目亦喜見新秀; 但另一邊廂，目睹部 分運動員已見老態或受傷患影響, 成績未如理想。值 得高興的是今屆亞殘運會, 香港殘奧會首次喜獲較完 整的後勤部隊-.---.-醫療、級別鑑訂、運動心理及秘書 處等同寅支援各運動隊伍，讓教練和運動員在參賽過 程中，無後顧之憂，專心致志比賽，實功不可沒。

3.6 今屆亞殘運會水平甚高, 競爭激烈, 馬來西亞及泰 國冒起甚快，相信離不開兩大因素------運動員趨職業 化及有關政府的全力支持所致。香港殘奧會運動員 雖是業餘性質，能贏取 5 金 9 銀 14 銅共 28 面獎牌，總 排名第7（亞殘運會官方網站，2010），殊非僥倖， 個中艱苦, 真非筆墨所能形容。除輪椅劍擊取得 3 金 6 銀 7 銅佳績是大贏家外, 田徑、賽艇和硬地滾球 亦能獲取獎牌，而羽毛球和保䶜球的金牌、射箭和 輪椅三級兵乓球的銅牌均在高手林立下贏取, 實屬 最大突破。有關上述資料、運動員成績和表現詳列 於秘書處（2011）和教練（2010及2011）報告內。

\section{（四）賽後檢討及建議}

4.1 大型運動會是測試教練和運動員的平台, 亦是考核秘書 處同事專業水平的機會。由備戰、訓練以至臨場與對手 較量, 教練們均親身體驗運動員的起與跌和成與敗, 於 賽後作出檢討, 繼而提出寶貴意見, 作為日後備戰的參 考。同樣地, 同事們對賽會敏鋭的觀察和對賽事作出專 業的評估, 亦可作為賽後檢討及調整各項目未來發展的 數據和藍本。

4.2 總括來説, 教練們和支援隊伍於賽後提出下列具體及富 建設性的意見：

* 場地是訓練的根源, 足夠及合適者至為重要;

* 發掘年青的新血亦刻不容緩, 可免青黄不接 (部分 項目已喜見新秀)；

* 運動員多有舊的傷患, 應儘早處理及治療, 可讓他 們具信心出賽(醫療隊伍於賽前親臨練習場地予以 協助)；

* 體能是比賽的成功要素, 足以影響能否贏取獎牌 (賽前加插體能訓練，教練和運動員於比賽中都能 體現其成效）；

* 運動心理學 (註4) 的介入能使運動員的表現予以提 升, 教練也獲益匪淺;
* 教練團的互補不足及相互支援, 使團隊更具信心, 因 為彼此了解自己的强與弱、機會與威脅; 同樣地, 秘書 處同事因分工而各司其職,但保持緊密聯繫,從而建 立默契、包容、協調和合作, 在體現團隊精神的大前 提下, 完成參加亞殘運會的工作。

\section{（五）總結}

5.1 在亞殘運會中, 喜見代表團24名新秀運動員成績可人,正如 周一劦會長在祝捷暨答謝晚會上所説：「…他們若加以环 磨, 想將來必成大器, ...」

5.2 級別鑑訂 (classification) 是殘疾人運動重要的一環, 運 動員必須經過級別鑑訂的程序, 才可參加比賽, 在殘奧 會及亞殘運會尤為重要。依據級別鑑訂的要求, 從而發 掘合適的運動員, 再加以訓練, 是奪取獎牌的要素。香 港殘奧會現準備投放資源在級別鑑訂上，希望不久的將 來在該議題上有突破性的進展。在亞殘運會中, 香港代 表團的馮英騏（註5）專責級別鑑訂工作，統籌有關事 宜, 相信對有關範疇未來的發展有一定的禆益。

5.3 亞殘運會後, 秘書處已和各項目主教練就運動員在亞殘 運的表現作深入及客觀的檢討和評估, 有助香港殘奧會 訂定未來的發展策略及工作方針。

5.4 亞殘運會競爭激烈, 水平之高, 僅次於殘奧會。中、 日、韓三國在比賽中盡領風騷, 馬來西亞、泰國及部分 西亞國家的迅速崛起，運動員的職業化及政府全力支持 實致勝原因。盼望香港特區政府能借鑑亞殘運會成績前 列國家的成功，對香港殘奧會相應增加支援 (人手及資 助），俾能促使殘疾人運動更趨專業、運動員更投入練 習，成績才可更上一層樓（伍澤連，2011）。

\section{（六）鳴謝}

「廣州2010年亞殘運會」中國香港代表團得以成行及得 以成功, 在 41 國家/地區殘奧會中總成績名列第 7 , 獲 5 金 9 銀 14銅共28面獎牌（亞殘運會官方網站，2010）佳績，實得來 不易，謹向下列各有關人士及機構致以衷心感謝：

* 亞組委圓滿擧辦亞殘運會, 妥善籌劃各項比賽, 悉心 照顧各代表團的衣、食、住、行, 讓各參賽國家/地區 殘奧會有一個充實和難忘的比賽 (註6)；

* 政務司唐英年司長、民政事務局曾德成局長、發展 局林鄭月娥局長、衛生及福利局周一猖局長（香港 殘奧會會長）、康文署馮程淑儀署長、民政局莫君 虞首席助理秘書長、香港殘奧會李國奎副會長及其 他嘉賓落臨比賽場地為港隊打氣; 
* 經香港殘奧會安排下, 8 間特殊學校鼎力支持, 派出 師生組成觀摩團, 親臨廣州為港隊打氣;

＊民政局及康文署對中國香港代表團的多方協助及資 助;

* 香港體育學院、中國香港賽艇協會、香港乒乓總會及 香港羽毛球總會提供技術協助;

＊ 市川洋行、名將制服有限公司贊助港隊制服；

＊香港中國旅行社有限公司為港隊安排交通及酒店

＊ 珠江船務有限公司、中港城、香港海關、入境處、海 事處作出適當及靈活的安排, 協助代表團順利進出 港口;

* 香港殘奧會馮馬潔嫻主席、林國基副主席及執委會 各成員對代表團的信任和支持;

* 代表團副團長、醫療隊伍、運動心理學家、教練及運 動員通力合作和多方包容。

最後, 香港殘奧會秘書處同寅在林俊英總幹事領導及鞭 策下, 均盡心盡力及熱誠地投入工作, 其專業及團隊精神在亞 殘運會中發揮得淋漓盡致, 致使代表團於廣州擧行的第一屆亞 殘運會中達至最佳成績, 正如本文作者在《懷念・一刻》團長 的話説：「場內外的喜與悲、笑與淚, 至今仍縈繞心間, 歷歴在 目。」

註 1：其他 5 大項包括自行車、5人制足球、7人制 足球、盲人門球和坐式排球。

註2： APC乃亞洲殘疾人奥林匹克委員會最高權力 機構，每4年選擧一次，於亞殘奧會的同人 大會中進行。

註3：3次測試賽中, 運動員必須以輪椅作賽, 亦是 測試前往廣州採用何種交通工具的好機會。

註4：運動心理學是首次介入代表隊的賽前準備, 促使運動員於比賽中有良好的表現，運動員與 教練均獲益良多。

註5：馮英騏乃香港殘奧會一名退役的傑出輪椅劍擊 運動員，現為博士研究生，專攻級別鑑訂，經 香港殘奧會推薦予IPC(國際殘奥會)，獲委任為 IPC轄下的級別鑑訂委員會成員。

註6：選手村村長孔少琼(2010)致辭説：「衣心祝您在 廣州亞殘運會取得您最好的成績，收穫最多的友 誼; 在廣州亞殘運會的日子，成為您永遠的美好 回憶。」

\section{參考文獻}

1 伍澤連(2011)：《廣州2010年亞殘運會中國香港代表團團 長報告》,香港,2011年1月25日。

2 香港殘疾人奧委會暨傷殘人士體育協會編訂 $(2010)$ ：《廣 州2010年亞殘軍會中國香港代表團單張》, 2010年10月23 日, 香港, 香港殘奧會。

3 香港殘疾人奥委會暨傷殘人士體育協會網頁, 香港, 2010 ○ http://www.hkparalympic.org

4 廣州2010年亞殘運會官方網站, 廣州, 2010 ○http://ww w. gzapg2010.cn

5 廣州2010年亞殘運會中國香港代表團秘書處報告(7份, 2011), 香港, 2011年1月。

6 廣州2010年亞殘運會中國香港代表團教練報告(14份， 2010及2011)，香港，2010年12月及2011年1月。

7 周一嶽(2011)：《廣州2010年亞殘運會中國香港代表團祝 捷暨答謝晚會致辭》, 香港, 2011年1月18日。

8 孔少琼(2010)：《亞殘運會運動員村住宿服務指南》, 頁4， 廣州2010年亞殘運會組委會編訂,廣州, 2010年12月。

9 香港殘疾人奥委會暨傷殘人士體育協會編訂 $(2011)$ : 廣州 2010年亞殘運會中國香港代表團紀念圖片集《懷念 - 一 刻》, 頁3,香港, 2011年1月18日。

10 伍澤連 $(2011)$ : 《政府可否加大資助殘疾人運動》, 文匯 報，2011年1月15日，體育版。

\section{通訊}

伍澤連

香港殘疾人奧委會暨傷殘人士體育協會 義務秘書

香港新界沙田美林邨美楓樓B座141-148地下

電話 : (852) 26028232

傳真 : (852) 26030106

電郵：patrickclng@yahoo.com.hk

\section{Correspondence:}

Patrick NG

Hong Kong Paralympic Committee \&

Sports Association for the Physically Disabled

Phone : (852) 26028232

Fax : (852) 26030106

Email : patrickclng@yahoo.com.hk 